being those of the Buddha. (Cf. the remarks of Dr. Waddell, u.s., p. 576.) - Yours truly,

Donald Ferguson.

5, Bedford Place, Croydon. January 9, 1897.

\title{
2. PiṣțĀpura.
}

SIR,-On p. 28 of the Society's Journal for January of this year, Mr. Vincent Smith gives us a list of kings and their kingdoms conquered, or at least temporarily defeated, by Samudra Gupta. The eleventh of these is the kingdom of "Piștâpura," with its king "Mahendragiri." I should like to point that while all the other names of kings given are veritable names of persons, "Mahendragiri" can hardly be anything but the name of a place.

Pisțâpuram (modern Pittâpuram) is, as Mr. Smith intimates (p. 2y), in the north of the present Godâvari District. Mahendragiri, a place very seldom visited by Europeans, lies within the limits of the present Zamindâri of Mandasa in the Ganjam District. There is a very ancient and very sacred temple there, to which frequent pilgrimages are made by the devout. Pittâpuram is undoubtedly a place of great antiquity. But it is difficult to see how the two places could be connected unless the old kingdom of Piștâpuram was in those days of far greater extent than has hitherto been supposed. One would expect to find Mahendragiri included in the kingdom of Kalingâ.-Yours faithfully,

R. SEwell.

3. The Coins of Acyuta, a prince defeated by Samudra Gupta.

British Museum, W.C.

Dear Professor Rhys Davids,- - Since the appearance, in the last number of the Journal, of Mr. Vincent Smith's Sperimen Chapter of a projected Ancient History of Northern 
India from the Monuments, I have found a number of bronze coins which, I think, must undoubtedly be attributed to the Acyuta, who is mentioned in the Allahabad inscription among the kings subdued by Samudra Gupta. The coins, which, so far as I know, have not hitherto been noticed, belonged formerly to General Sir A. Cunningham, and are now in the British Museum. They bear on the obverse the abbreviated name $A c y u$ - in Gupta characters, precisely similar to those of the Allahabad inscription; and their reverse type is a wheel. In their general character they resemble the coins of the Nāga kings of Padmāvatī or Narwar, one of whom, Ganapati Nāga, is mentioned together with Acyuta in the Allahabad inscription. Indeed, the same reverse type, a wheel, actually occurs on the coins of another member of this dynasty-Deva Näga (see Cunningham's Coins of Mediaeval India, pl. ii, 24). Nāga Datta and Nāga Sena, who are also mentioned in the Allahabad inscription, are probably other members of the same family; but the precise relationship of these princes to one another remains to be determined. The only suggestion which occurs to me at present is that, possibly, all the nine kings whose names occur together in this passage may have been Nāgas; and that the term "Nine Nāgas," used in the Viṣnu Purāṇa (trans. Wilson, p. 479), may, perhaps, refer not, as has been hitherto assumed, to a dynasty of nine members, but to this confederation of nine princes belonging to the same race.

E. J. Rapson.

\section{Kapitthik̄̄a ; KapítTha.}

Dear Sir,-The Madhuban plate of the great king Harsadeva of Kanauj was issued from Kapitthika; for the reading of the original plate, in line 1 , clearly is mahanauhastyaśvajayaskandhãvârāt $=$ Kapitthikāyāh, and not, as Professor Bühler's published text (Ep. Ind., vol. i, p. 72) has it, 'skandhāvārāt Pinthikāyāh. Kapitthikā apparently 